\title{
A case of cutaneous larva migrans from Turkey
}

\section{Przypadek zespołu wędrującej larwy skórnej w Turcji}

\author{
Sevda Önder', Murat Öztürk², Hilayda Karakök Güngör' ${ }^{1}$ Havva Erdem³ \\ 'Department of Dermatology, Faculty of Medicine, Ordu University, Ordu, Turkey \\ ${ }^{2}$ Health Sciences University, Van Training and Research Hospital, Van, Turkey \\ ${ }^{3}$ Department of Pathology, Faculty of Medicine, Ordu University, Ordu, Turkey
}

Dermatol Rev/Przegl Dermatol 2021, 108, 325-328

DOI: https://doi.org// 0.5 | |4/dr.2021. I 10732

Cutaneous larva migrans (CLM) is an infestation that occurs with the penetration and migration of larvae of animal (especially cat and dog) hookworms into the epidermis. The disease occurs as a result of contact with the faeces of infected animals. It is observed as itchy erythematous migrating and serpiginous slightly raised eruptions [1]. CLM is seen endemically in some regions. These are Central and South America, Mexico, Caribbean, Africa, Southeast Asia, Mediterranean regions, the south-eastern parts of the United States, and some other tropical areas. It is the most common skin disease seen after traveling to tropical and subtropical regions [1-3]. However, when we look at the literature, cases have been reported in non-endemic regions like our country [4]. A small number of CLM cases have been reported in our country. While 4 of them were autochthonous, 4 of them had a history of traveling to the endemic region [2, 3, 5-7]. Although facilitating the transportation between countries makes it easier to see the disease, global warming and its effects make it easier to see some parasitic diseases in non-endemic regions as a result of changes of both climate and environment.

A 45-year-old male patient presented to our outpatient clinic with an itchy lesion that started on the thigh for 2 weeks and spread from the hips to the trunk over time. The patient was an office worker, but stated that he was dealing with garden work on the weekend. The patient had no recent travel history abroad. He had no other known diseases. He did not benefit from the topical steroid treatment he used for 2 weeks.

On dermatological examination, there was a lesion of about $10 \mathrm{~cm}$ in length on an erythematous floor that spread to the back on the right side of the trunk (fig. 1). In laboratory tests, eosinophilia was noteworthy. In the skin biopsy examination, chronic inflammation with perivascular and eosinophils was evident (fig. 2). With these signs and symptoms, a diagnosis of CLM was
Zespół wędrującej larwy skórnej (cutaneous larva migrans - CLM) jest chorobą, która rozwija się wskutek wniknięcia do naskórka wędrujących larw różnych gatunków tęgoryjców (występujących głównie u kotów i psów). Człowiek zaraża się przez kontakt z odchodami zakażonych zwierząt. Zmiany skórne w przebiegu CLM mają postać wędrującego swędzącego rumienia oraz lekko uniesionych zmian o charakterze pełzającym [1]. CLM występuje endemicznie w niektórych regionach świata, do których należą: Ameryka Środkowa i Południowa, Meksyk, Karaiby, Afryka, Azja Południowo-Wschodnia, rejon Morza Śródziemnego, południowo-wschodnie Stany Zjednoczone oraz niektóre inne obszary tropikalne. CLM jest najczęstszą chorobą skóry u osób podróżujących do regionów tropikalnych i subtropikalnych [1-3]. Przegląd piśmiennictwa wskazuje jednak, że CLM może występować także w regionach nieendemicznych, m.in. w Turcji [4], gdzie odnotowano niewielką liczbę przypadków. Cztery przypadki miały charakter autochtoniczny, natomiast u kolejnych 4 pacjentów ustalono, że przebywali w regionie endemicznego występowania choroby [2, 3, 5-7]. Mimo że usprawnienie transportu między krajami ułatwia śledzenie chorób, schorzenia pasożytnicze wskutek globalnego ocieplenia i jego skutków klimatycznych oraz środowiskowych są coraz częściej obserwowane w regionach wcześniej nieendemicznych.

Mężczyzna 45-letni zgłosił się do naszej poradni z powodu zmiany skórnej z towarzyszącym świądem, która pojawiła się 2 tygodnie wcześniej na udzie, a następnie zajęła skórę od bioder do tułowia. Pacjent był pracownikiem biurowym, ale oświadczył, że w weekendy zajmuje się pracami ogrodniczymi. W okresie poprzedzającym wystąpienie zmiany nie wyjeżdżał za granicę. W wywiadzie nie podawał innych chorób. Przez 2 tygodnie mężczyzna stosował miejscowe leczenie glikokortykosteroidami, które okazało się nieskuteczne. 


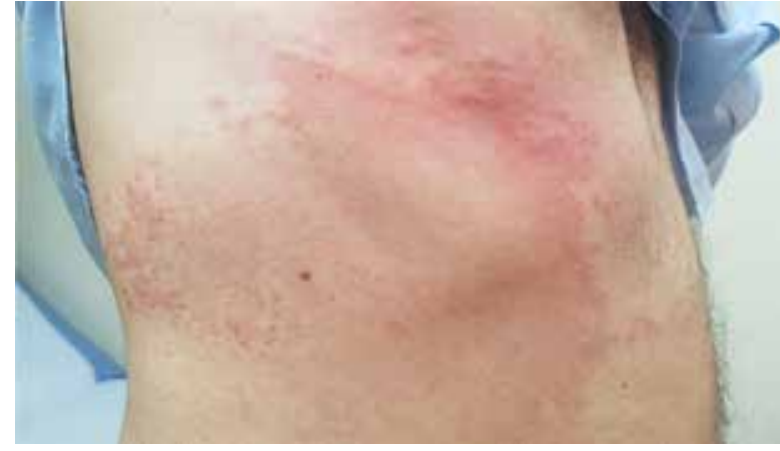

Figure I. Before treatment

Rycina I. Przed leczeniem

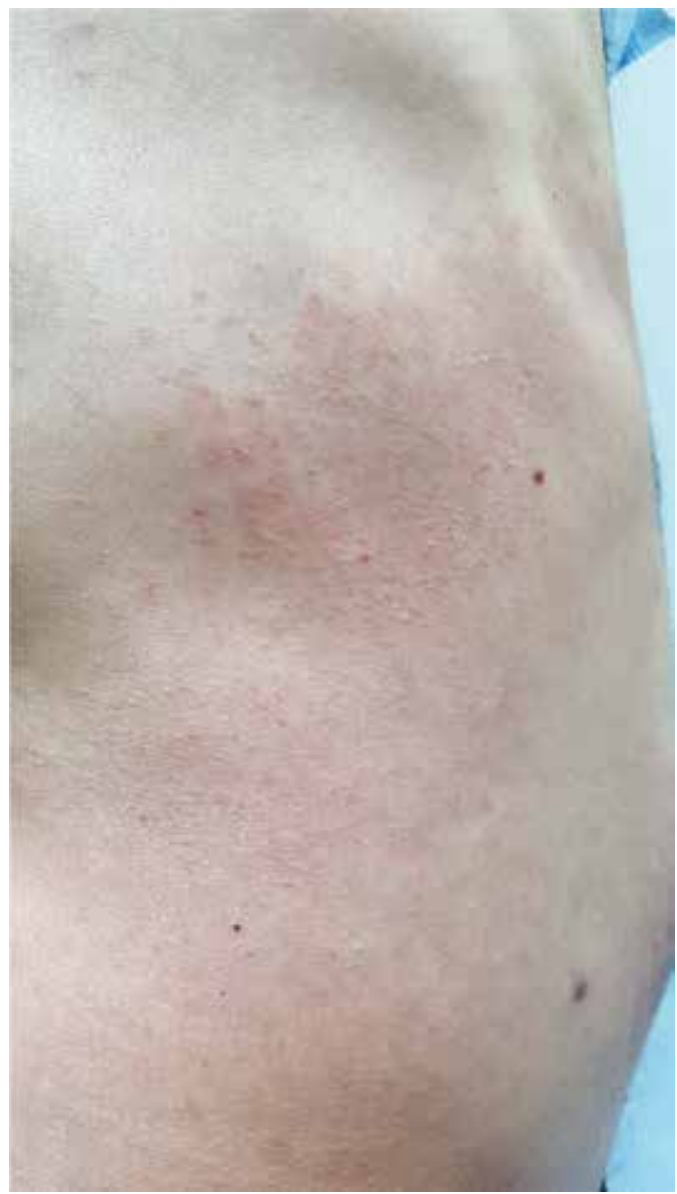

Figure 3. One week after treatment

Rycina 3. Tydzień po leczeniu

made. As treatment, $800 \mathrm{mg}$ albendazole was given for 3 days. After the treatment, the patient's complaints disappeared completely (fig. 3). The patient was followed up for complications that may develop in the late period.

Although many different larvae can cause CLM, the most common factors are Ancylostoma braziliense and Ancylostoma caninum. Humans are accidental hosts. Filariform larvae penetrate the skin as a result of direct contact with contaminated soil or sand [8].

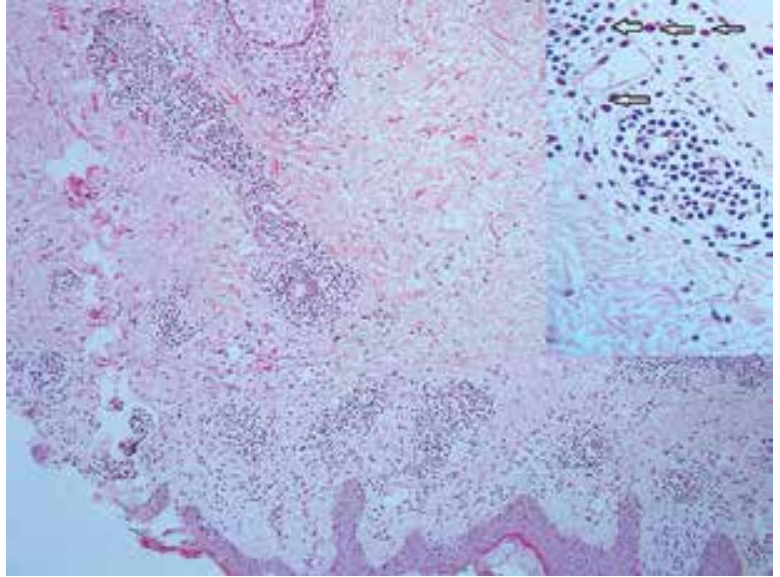

Figure 2. Perivascular, chronic inflammation where eosinophils are evident $(\mathrm{H}+\mathrm{E}, \mathrm{I00} \times)$, eosinophils are seen at large magnification (arrows) $(\mathrm{H}+\mathrm{E}, 400 \times)$

Rycina 2. Przewlekłe okołonaczyniowe zmiany zapalne z eozynofilami (barwienie $\mathrm{H}+\mathrm{E} ; 100 \times$ ). Przy dużym powiększeniu widoczne eozynofile (strzałki) $(H+E, 400 \times)$

W badaniu dermatologicznym stwierdzono zmianę o długości około $10 \mathrm{~cm}$, na podłożu rumieniowym, która występowała na skórze pleców po prawej stronie (ryc. 1). W badaniach laboratoryjnych wykazano eozynofilię. $\mathrm{W}$ badaniu histopatologicznym stwierdzono okołonaczyniowe zmiany zapalne oraz obecność eozynofilów (ryc. 2). Na podstawie całości obrazu rozpoznano CLM. Wdrożono leczenie albendazolem w dawce $800 \mathrm{mg}$, stosowanym przez 3 dni. Po zakończeniu terapii stwierdzono całkowite ustąpienie zmian (ryc. 3). Pacjent został objęty dalszą obserwacją pod kątem ewentualnych późnych powikłań zakażenia.

Mimo że CLM jest wywoływany przez larwy różnych gatunków tęgoryjców, najczęściej są to Ancylostoma braziliense i Ancylostoma caninum. Ludzie są przypadkowymi gospodarzami dla tych pasożytów. Nitkowate larwy wnikają w skórę wskutek bezpośredniego kontaktu z zakażoną glebą lub piaskiem [8], a następnie przemieszczają się w obrębie naskórka dzięki dwóm enzymom: proteazie i hialuronidazie. Larwy nie mają jednak enzymu kolagenazy, co uniemożliwia ich przenikanie przez skórę właściwą. W rezultacie nie docierają do naczyń krwionośnych i limfatycznych, a zatem nie mogą ukończyć cyklu życiowego w organizmie człowieka [9]. Rzadko zdarzają się przypadki, w których na skórze pacjentów widoczne są zmiany grudkowe i pęcherzykowe $[1,3,5]$. Choroba ma charakter samoograniczający. Larwy zwykle giną samoistnie $\mathrm{w}$ tkance podskórnej w czasie 2-8 tygodni $[3,5]$. W piśmiennictwie można znaleźć tylko sporadyczne doniesienia o rozsiewie do narządów wewnętrznych [1]. Zmiany skórne najczęściej umiejscawiają się w okolicy stawów skokowych i stóp, na kończynach dolnych, skórze w okolicy stawu biodrowego i udach. W literaturze można również znaleźć publikacje opisujące rzadkie lokalizacje obejmujące skórę twarzy, kończyn górnych, 
Then they migrate in the epidermis by protease and hyaluronidase enzymes. The larvae do not have a collagenase enzyme and therefore cannot penetrate the dermis so that they cannot reach the blood or lymphatic vessels, as a result, they cannot complete their life cycle in humans [9]. Rarely, there may be cases in which papular and vesicular lesions are seen $[1,3,5]$. The disease is self-limiting. Larvae usually die in the subcutaneous tissue within 2 to 8 weeks $[3,5]$. However, migration to internal organs is rarely reported in the literature [1]. Regions where lesions are most common include ankles, feet, legs, hips and thighs. It has been reported in the literature that it is rarely seen in unusual areas such as the face, upper extremities, trunk, abdomen, breast, oral cavity, genital area and perineal regions $[1-3,5]$. Multifocal presentation can be seen as atypical involvement [10]. In our case, the lesions started on the thigh and spread to the trunk. There was no direct contact with the soil, but our patient stated that he worked in the garden on weekends. The diagnosis is usually made clinically $[4,5]$. Especially warm and humid climates, loose soil and shady areas are suitable areas for the survival of the larvae and the emergence of the disease in these areas becomes easier $[2,5]$. Our region is in the Black Sea region and generally has a rainy and temperate climate.

In one article, 5 autochthonous cases were reported in France, a non-endemic region. In the mentioned article, 55 autochthonous cases between 1994 and 2018 were evaluated and it was pointed out that the occurrence of the disease in non-endemic regions may be related to global warming [4]. We agree with this idea of the authors. However, it is difficult to express a clear idea as there is not enough data on this subject. Studies in non-endemic regions are needed.

Laboratory tests show eosinophilia and increased serum total IgE levels. Biopsy is generally not helpful in diagnosis and has low sensitivity, it is difficult to see larvae in biopsy specimens $[1,2]$. In our patient's blood picture, eosinophilia and eosinophils in the skin biopsy specimen were noteworthy. The chest radiograph was normal. Dermoscopy, a useful bedside tool, aides in differentiating it from burrow of scabies, larva currens, and dracunculiasis. Sil et al. detected multiple white beaded structures arranged in a serpiginous pattern over an erythematous background on dermoscopy of a case [11].

The most common complications of the disease are bacterial infection and eczema. Loeffler's syndrome may rarely develop, characterized by migratory pulmonary eosinophilic infiltrates and peripheral blood eosinophilia $[2,3]$. There was no complication in our patient.

Oral ivermectin and oral albendazole are a treatment option for CLM [1]. Systemic treatment was given because the lesions of our case were common and tułowia, brzucha i sutków, a także jamę ustną, okolicę narządów płciowych i krocza [1-3, 5]. Nietypową manifestacją zakażenia są zmiany wieloogniskowe [10]. U opisywanego przez nas pacjenta zmiany skórne pojawiły się na udzie, a następnie rozprzestrzeniły na tułów. Pacjent nie miał bezpośredniego kontaktu z glebą, ale podał, że $\mathrm{w}$ weekendy pracuje w ogrodzie. Rozpoznanie CLM zwykle ustala się na podstawie obrazu klinicznego [4, 5]. Rozwojowi larw sprzyja ciepły i wilgotny klimat, luźna gleba oraz obecność zacienionych obszarów. W takich miejscach można obserwować występowanie zakażeń $[2,5]$. Opisywany przez nas pacjent mieszkał $w$ regionie Morza Czarnego, gdzie klimat jest umiarkowany, z dość dużą ilością opadów.

$\mathrm{W}$ jednej z prac dostępnych w piśmiennictwie opisano 5 autochtonicznych przypadków CLM we Francji, która jest regionem nieendemicznym. W pracy tej poddano analizie 55 przypadków autochtonicznych zarejestrowanych w latach 1994-2018. Zdaniem autorów występowanie choroby $w$ regionach nieendemicznych może mieć związek z globalnym ociepleniem [4]. Podzielamy ten pogląd, choć należy zaznaczyć, że hipoteza ta wymaga dalszej weryfikacji ze względu na brak wystarczającej liczby danych. Niezbędne są dalsze badania w tym kierunku prowadzone $\mathrm{w}$ regionach nieendemicznych.

$\mathrm{W}$ badaniach laboratoryjnych wykonywanych $\mathrm{u}$ pacjentów stwierdza się eozynofilię i podwyższone stężenie całkowitego IgE w surowicy. Biopsja skóry z reguły nie jest przydatna diagnostycznie ze względu na niską czułość oraz trudności z dostrzeżeniem larw w wycin$\mathrm{ku}[1,2]$. U naszego pacjenta w obrazie krwi zwracała uwagę eozynofilia, a także obecność eozynofilów w wycinkach z skóry. W badaniu RTG klatki piersiowej nie stwierdzono odchyleń od normy. Dermoskopia, użyteczna diagnostyczna metoda przyłóżkowa, pomaga w różnicowaniu CLM z tunelami świerzbowcowymi, larva currens i drakunkulozą. W jednym z przypadków Sil i wsp. w badaniu dermatoskopowym wykryli liczne białe, paciorkowate struktury o charakterze pełzającym, umiejscowione na podłożu rumieniowym [11].

Do najczęstszych powikłań CLM należą zakażenie bakteryjne oraz wyprysk kontaktowy. Rzadko u chorych może rozwijać się zespół Loefflera, który cechuje się obecnością przemijających nacieków eozynofilowych w płucach i eozynofilią we krwi obwodowej [2, 3]. U naszego pacjenta nie wystąpiły jednak żadne powikłania.

Do opcji terapeutycznych w CLM należy leczenie iwermektyną stosowaną doustnie i albendazolem [1]. U naszego pacjenta zastosowano terapię ogólną, ponieważ zmiany były nasilone i utrzymywały się przez 2 tygodnie. Leczenie albendazolem $800 \mathrm{mg}$ (w dawce maksymalnej) spowodowało całkowite ustąpienie zmian.

Przedstawiony przypadek pokazuje, że wskutek globalnego ocieplenia $\mathrm{w}$ tym regionie Turcji powstały siedliska sprzyjające bytowaniu larw tęgoryjców, choć należy podkreślić, że liczba badań dotyczących tego 
continued for 2 weeks. Albendazole 800 mg (maximum dose) completely improved the lesions.

As a result, we think that our region has created a suitable habitat for larvae with the effects of global warming, but the number of studies on this subject in our country and non-endemic regions is low. Our case responded quickly to albendazole treatment. We present our case in order to draw attention to the fact that the disease can be seen in non-endemic regions .

\section{CONFLICT OF INTEREST}

The authors declare no conflict of interest. zagadnienia, zarówno w tym kraju, jak i w regionach nieendemicznych, jest niewielka. Opisywany przez nas pacjent szybko zareagował na leczenie albendazolem. Przypadek ten zaprezentowano, aby zwrócić uwagę na fakt, że CLM może również występować w rejonach nieendemicznych.

\section{KONFLIKT INTERESÓW}

Autorzy nie zgłaszają konfliktu interesów.

\section{References \\ Piśmiennictwo}

1. Leung A.K.C., Barankin B., Hon K.L.E.: Cutaneous larva migrans. Recent Pat Inflamm Allergy Drug Discov 2017, 11, 2-11.

2. Sönmezer M.Ç., Erdinç Ş., Tülek N., Babür C., Büyükdemirci A., İlgar T., et al.: Cutaneous larva migrans in Turkey: an imported case report. Mikrobiyol Bul 2017, 51, 94-99.

3. Yavuzer K., Ak M., Karadag A.S.: A case report of cutaneous larva migrans. Eurasian J Med 2010, 42, 40-41.

4. Del Giudice P., Hakimi S., Vandenbos F., Magana C., Hubiche T.: Autochthonous cutaneous larva migrans in France and Europe. Acta Derm Venereol 2019, 99, 805-808.

5. Çalışkan E., Uslu E., Turan H., Başkan E., Kılıç N.: Cutaneous larva migrans: report of three cases from the Western Black Sea Region, Turkey. Mikrobiyol Bul 2016, 50, 165-169.

6. Aktas H., Gulec A.I., Ergin C., Sürücü F.: Zosteriform cutaneous larva migrans in a nontropical geography: successful treatment with oral albendazole. J Turk Acad Dermatol 2016, 10, 16101c7.

7. Oral A., Ölmez Ö., Bambul N.: A case of cutaneous larva migrans in Turkish patient. Int J Clin Med Imaging 2016, 3. DOI: 10.4172/2376-0249.1000457.

8. Karthikeyan K., Thappa D.: Cutaneous larva migrans. Indian J Dermatol Venereol Leprol 2002, 68, 252-258.

9. Feldmeier H., Schuster A.: Mini review: hooked worm related cutaneous larva migrans. Eur J Clin Microbiol Infect Dis 2012, 31, 915-918.

10. Sil A., Mukherjee G.S., Bhanja D.B., Panigrahi A.: Multiple curvilinear lesions on a patient's back. Neth J Med $2020,78,92$.

11. Sil A., Panigrahi A., Bhanja D.B., Chakraborty S.: Cutaneous larva migrans over penis. Urology 2020, 140, e6-e7.

Received: 30.07 .2020

Accepted: 11.11 .2020

Otrzymano: $30.07 .2020 \mathrm{r}$.

Zaakceptowano: 11.11.2020 r.

How to cite this article

Önder S., Öztürk M., Güngör H.K., Erdem H.: A case of cutaneous larva migrans from Turkey. Dermatol Rev/Przegl Dermatol 2021, 108, 325-328. DOI: https://doi.org/10.5114/dr.2021.110732. 